\title{
Study of the skills of construction labours in building construction projects in Padang City
}

\author{
Benny Hidayat ${ }^{1 *}$, Lilis Novitasari ${ }^{1}$, and Taufika Ophiyandri ${ }^{1}$ \\ ${ }^{1}$ Department of Civil Engineering, Universitas Andalas, Padang, Indonesia
}

\begin{abstract}
Labor is one of the most important elements of a construction projects. This is attributed to their role as technical workforce that involved in the construction projects from the start to the end of the projects. Therefore, the projects require a workforce with good competence. Competence of direct labor can be verified with certification. However, from National Statistics Beaureu (BPS) data indicates that less than $10 \%$ of direct labor has certification. This study aims to measure the level of competence of direct workforce skills and know the factors that cause the workforce does not have a skill certificate. This research uses an observation method and interviews with labor in the construction project. Validation of data is done by the triangulation technique. The results showed that the competence of labour in Padang City included in the good category. Factors impeding direct labor to certification are certification is not important in a construction project, and there is no requirement for a workforce to be certified.
\end{abstract}

\section{Introduction}

Labors are one of the critical elements in the implementation of construction projects. Some research on project management shows that various challenges: for example, cost overruns [1], delays [2], re-work [3], are the results of low skill labor. In reconstruction after disaster context, the skill of the labors is one of a crucial factor to successful reconstruction after a disaster $[4,5]$. Labor and construction workers in general, work to realize drawings into finished products, such as concrete buildings, by operate types of equipment and convert raw materials. Construction works rely heavily on the workers. Therefore the skill of the workers may significantly affect quality, schedule, or cost of projects. In this paper, we use the term labor to define worker that involve directly in the field, commonly known in Indonesian as 'tukang' to differentiate with professionals or tradespersons that also may be titled as construction workers.

The skills of the labor can be evaluated by their competency in doing work. Competent means they capable and have the required skills to perform the works. In Indonesia, it recognized by the competency certificate and the certification process is according to Standard Kompetensi Kerja Nasional Indonesian (SKKNI, Indonesian Standards for Work Competencies). For the builders, it noted as role F.410100 in Ministry of Manpower and Transmigration Decree No. 31-2014.

\footnotetext{
* Corresponding author: bennyhidayat@eng.unand.ac.id
} 
A certification is a process of appraisal to gain recognition of a person's competence, to meet the requirements of the law through a competency test [6]. The purpose of certification is to provide assurance on the skills, quality, and skills of construction workers, to produce construction products that meet the established quality standards. The implementation of certification is expected by the Indonesian Government to be a way to open opportunities for job access in construction projects on a competitive basis at the global level.

Yamu'alim [7] also defines competence certification as a process of providing competency certificates that are conducted systematically and objectively through a competency test which refers to the standard of work competence both nationally and internationally. By having a competency certificate in a field of work, then a worker will have written the proof of recognition for the competence.

\section{Methodology}

This study has an aim to measure the level of skill of construction labor and to identify factors that prevent the workers to get certification. The study is focussed on three categories of labor as respondents: masons, craftsmen, and carpenters. Three construction projects in Padang City, West Sumatra Province Indonesia, were chosen as locations of the study. For each project, observations and interviews were conducted with 5 masons (bricklayers), 5 rebar-man (blacksmith), and 5 carpenters. So, in total there was 45 labor as respondents in this study.

\subsection{Data Collection}

\subsubsection{Observation}

Direct observation of the labors conducted observations in this study as the research sample. A form was created and used for observation in this research's data collection. The observation was nonparticipant, where the author only as an observer for the benefit of research data and not involved with the activities been working by the respondents. The author only observes, notes, analyzes, and then can make conclusions based on data that has been analyzed.

Observations were made on the sample of the respondent's category with the specified amount, total 15 labors in each project. Observations were made over two weeks (14 days) in each project. Observations were conducted using instruments in the form of observation sheets that refer to SKKNI. The observation sheets use a rating scale, using a score range of 1 to 4 , where a score of $4=$ no errors, score $3=$ there is a slight error, score $2=$ there are many errors, and score $1=$ not perform.

\subsubsection{Interview}

Interviews are also conducted in this research, to find out in-depth information from the respondents. A structured interview was chosen, and then an interview guideline was prepared and then used to interview. There were a total of 45 respondents in the interview.

\subsection{Data analysis}

Data analysis method used in this research are scoring and tabulation. Scoring is used to measure the skill level of construction workers in the city of Padang. Tabulation is used to 
find out the respondent description, and the causal factors that lead to the labors do not have skill certificate. Data analysis using a scoring method, by comparing the total score obtained with the maximum score then multiplied by $100 \%$.

Meleong [8] stated that for the results of research can be accounted for then it requires a check whether the data presented is valid or not, so it needed validation techniques/ data validation. The data used was obtained from direct observation of the workforce to identify the level of skills in carrying out their work. In this study, data validation uses source triangulation to compare the degree of confidence of information obtained through different resource of assessment. The triangulation is implemented by comparing the assessment results between the Researcher, the foreman, and the project implementer. The triangulation is shown in Fig.1.

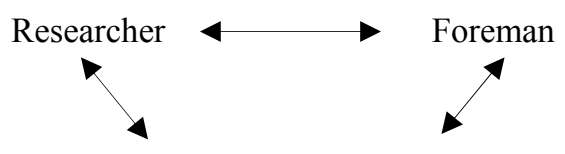

Project implementers

Fig. 1. Triangulation of resources.

Furthermore, to identify the category of the skill level of the labors, it refers to the table of interpretation of skills scores in Table 1.

Table 1. Interpretation of labor skills.

\begin{tabular}{|c|c|}
\hline Score & Category \\
\hline $70-100$ & Good \\
\hline $50-69$ & Sufficient \\
\hline$<50$ & Poor \\
\hline
\end{tabular}

\section{Results and discussion}

\subsection{Observation}

Recapitulation of work skills is the result of skill assessment of labor obtained through observation method using observation sheet. Table 2 below shows the skill level of the mason in the city of Padang is categorized in the excellent category, with the score of 72.00. The skill level of rebar-men in the city of Padang included is in the category sufficient, with a score of 67.78. Then the skill level of the carpenter in the city of Padang included is in a good category, with a score of 73.49. For overall, Table 2 above shows that the skill level of the labors in Padang is categorized good, with the score of 71.09.

\subsection{Interview}

\subsubsection{Training}

Fig. 2 shows that from 45 respondents, $40 \%$ said they had attended training for builders. The training they attended were from the construction company where they worked before. 
Table 2. Recapitulation of labor skills level in Padang city.

\begin{tabular}{|c|c|c|c|c|}
\hline \multicolumn{5}{|c|}{ Recapitulation } \\
\hline No & Category & Project A & Project B & Project C \\
\hline \multirow[t]{4}{*}{1} & \multicolumn{4}{|l|}{ Bricklayers } \\
\hline & 1. Implementing Occupational Safety and Health & 39.58 & 92,71 & 25.00 \\
\hline & 2. Implementing a Brick layer & 83.33 & 87.50 & 80.56 \\
\hline & 3. Implementing Plastering Work & 96.43 & - & - \\
\hline & Mean & 73.12 & 90.10 & 52.78 \\
\hline \multicolumn{2}{|r|}{ Mason/Bricklayers' skill scores } & \multicolumn{3}{|c|}{72.00} \\
\hline \multirow[t]{3}{*}{2} & \multicolumn{4}{|l|}{ Rebar-men } \\
\hline & 1. Implementing Occupational Safety and Health & 37.50 & 66.67 & 25.00 \\
\hline & 2. Carrying out Iron Replacement Work & 93.75 & 93.33 & 90.42 \\
\hline & Mean & 65.63 & 80.00 & 57.71 \\
\hline \multicolumn{2}{|r|}{ Rebar-men skill score } & \multicolumn{3}{|c|}{67.78} \\
\hline \multirow[t]{3}{*}{3} & \multicolumn{4}{|l|}{ Carpenter } \\
\hline & 1. Implementing Occupational Safety and Health & 40.83 & 76.67 & 25.00 \\
\hline & 2. Installing Wood Formwork & 99.48 & 99.48 & 99.48 \\
\hline & Mean & 70.16 & 88.07 & 62.24 \\
\hline \multicolumn{2}{|r|}{ Carpenter skill score } & \multicolumn{3}{|c|}{73.49} \\
\hline & Total Mean & 69.63 & 86.06 & 57.58 \\
\hline & Final score & 71.09 & & \\
\hline
\end{tabular}

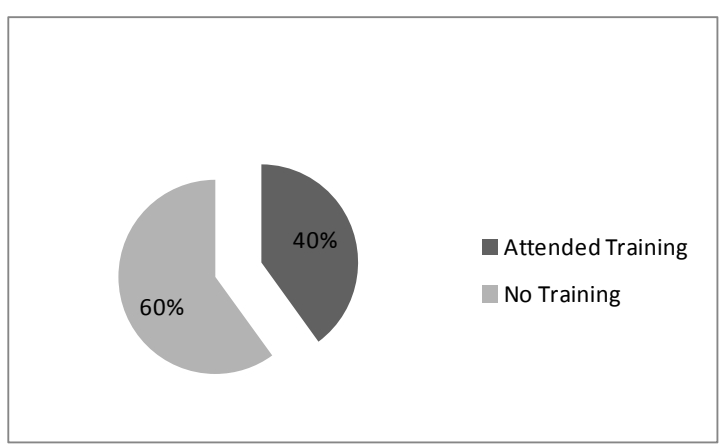

Fig. 2. Participation of manpower training in Padang city. 
Respondents of this research were divided into two groups, who have attended training and have not attended any training before.

From Fig. 3 the results of the skill level show that the skill level of the workforce that has had training is slightly higher than no-training workers. This indicates that training is needed to improve the skills of the labors.

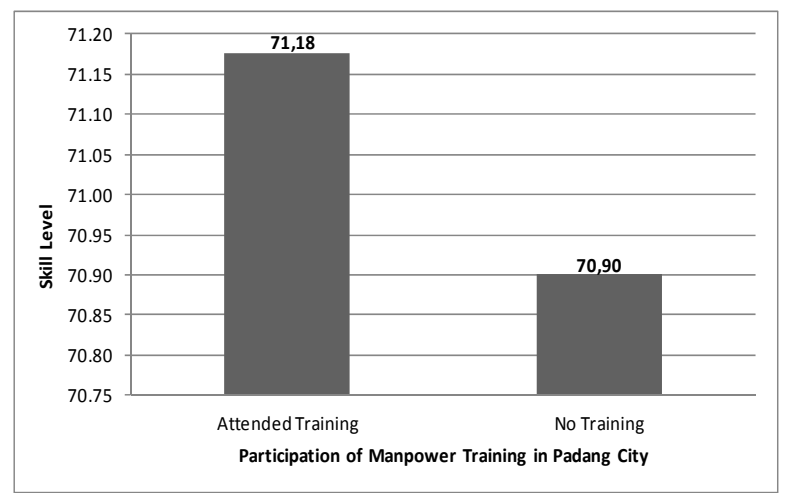

Fig. 3. The Effect of training on manpower skills in Padang city.

\subsubsection{Skill certification test}

Fig. 4 shows from 45 respondents, 13\% of them said they had taken a skill certification test. From the previous figures (Fig. 2) it is known that the workforce attending the training is $40 \%$. This indicates that there are $27 \%$ of the labors who have participated in the practice but did not take the skill certification test. This is because their company only provides training, but without support for a skill certificate test. Therefore, the labors simply follow the procedures given by the company.

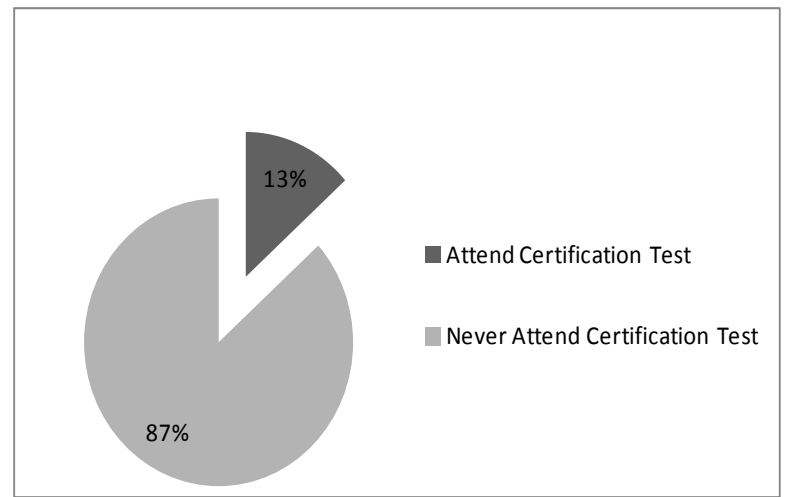

Fig. 4. Participation of labor skills certification test in Padang city.

\subsubsection{Certificate ownership}

Fig. 5 shows from 45 respondents, only $13 \%$ stated that they have a valid skill certificate. This shows that about $87 \%$ of the workers do not have a skill certificate. Fig. 6 shows that the skill level indicates that the certified labor skills level produces a higher score than those without a skill certificate. 


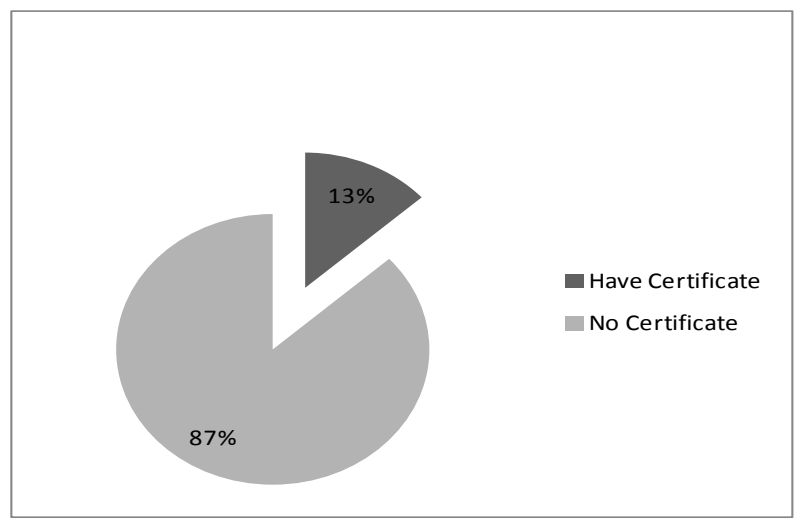

Fig. 5. Ownership of manpower skills certificate in Padang city.

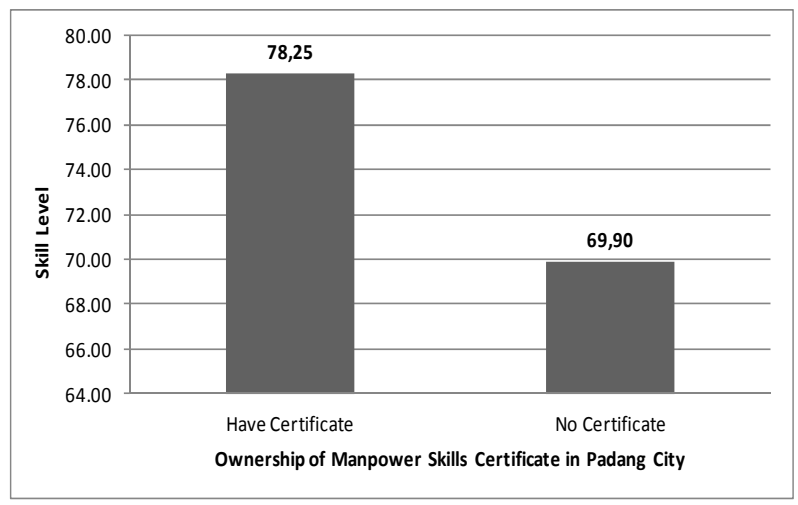

Fig. 6. The Effect of ownership of certificate of manpower skill in Padang city.

\subsubsection{Factors prohibit skill certification}

Results show there are various factors that cause the labors do not have a certificate of skill competence in Padang City. From certificate ownership (Fig. 4) it has been described as many as 45 respondents, there are $87 \%$ or 39 respondents who do not have a certificate of skill. From the structured interviews to respondents who do not have a certificate, it can be identified many factors that prohibit the labors to get certification, as can be seen in Fig. 7.

It can be seen that 39 respondents who do not have a certificate stated they can still get a job without having a license of expertise (Fig. 7). This is because the skills certificate that has become a form of skill recognition is not a requirement for the construction project work. Without a certificate of skill, they can still get a job in a construction project.

Furthermore, as many as 35 respondents from 39 respondents who do not have a certificate stated that there is no socialization from their company about the benefits for the labors to have the skill certificate. This may lead to less skilled labor. Another impact of the lack of socialization resulted in ignorance of information about the application of a skill certificate. There are 11 respondents from 39 respondents who do not have a license of expertise stated that they have a lack of confidence to take the certification test because their education level is low. 


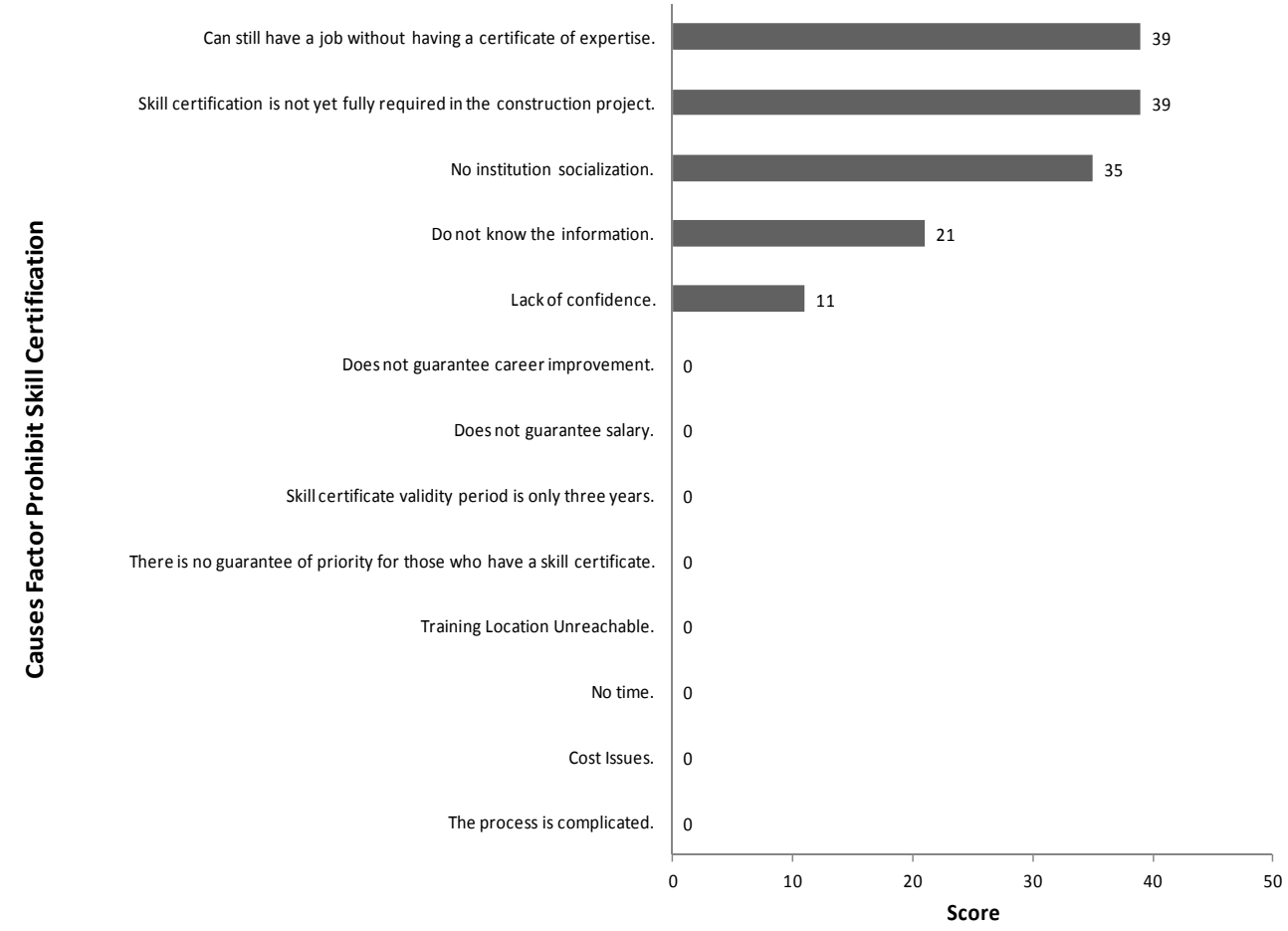

Fig. 7. Causes factor prohibit skill certification.

\section{Conclusions}

Based on the research results, some conclusions can be drawn as follows. The skill level of the labors of construction projects in Padang city is categorized as good with a score of 71.09. Some factors that prohibit the labors to have a skills certificate are: 1) the labors still have a job without having a skill certificate, 2) skill certification is not yet fully required in the construction project, 3) no institution socialization, 4) the labors do not know the information about certification, 5) lack of confidence to get certification test.

\section{References}

1. I. Santoso, Dimensi Teknik 1, 1 (1999)

2. I.A.R. Widhiawati, Teknologi Elektro 8, 2 (2009)

3. A. Herdianto, A. Dewi, R. Tanjungsari, A. Hidayat, J.U. Dwi. J. Karya Teknik Sipil 4, 1 (2015)

4. B. Hidayat, C. Egbu, Proceedings of 27th Annual ARCOM Conference (2011)

5. B. Hidayat, Z. Afif, AIP Conference Proc. 1903 (2017)

6. H.P. Adi, S.U. Adillah, J. Karya Teknik Sipil 1, 1 (2012)

7. Yamu'alim, Forum Manajemen, 6, 1 (2016)

8. L. Meleong, Metode penelitian kualitatif(PT Rosdakarya, Bandung, 2014) 